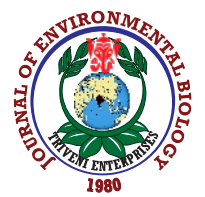

\title{
Carbon fractions of fortified thermochemical organic fertilizers and their response on the yield of okra and tomato
}

\author{
N. Leno*, G. Jacob, J. Jayakrishna, S.R. Kavya, M.K. Krishnapriya, L. Taki, M.M. Sreelakshmi, M.R. Rehana and A.B. Vijay \\ Department of Soil Science and Agricultural Chemistry, College of Agriculture, Kerala Agricultural University, Trivandrum-695 522, India \\ *Corresponding Author Email : n.leno@kau.in
}

\begin{tabular}{lll}
\hline Received: 04.01.2021 & Revised: 08.04.2021 & Accepted: 08.06.2021 \\
\hline
\end{tabular}

\section{Abstract}

Aim: To study the carbon fractional status of the growing media and to find out the best organic nitrogen source for fortification of thermochemical organic fertilizer, the manurial constituent of growing media for container cultivation of okra and tomato.

Methodology: Container cultivation of okra and tomato were done in completely randomised design. Treatments included fortification with farmyard manure, neem cake, groundnut cake, poultry manure, vermicompost, coir pith compost, hatchery waste organic fertilizer, urea and unfortified thermochemical organic fertilizer. Carbon fractions, viz. total organic carbon, permanganate oxidisable labile carbon, microbial biomass carbon and soil respiration of the growing media were analysed. The yield and yield attributes of the crops were determined.

Results: Irrespective of the organic source of nitrogen used, the fortified thermochemical organic fertilizer imparted a high status of total organic carbon to the growing media. Fortification with farmyard manure enhanced labile carbon, soil microbial biomass carbon and soil respiration over those fortified with other organic and inorganic sources. Container grown okra in a growing media with thermochemical organic fertilizer fortified with farmyard manure out yielded urea based fortification by $55.96 \%$. Tomato grown in coir pith compost fortified growing media enhanced yield by $27.37 \%$ over the groundnut cake fortified growing media. Linear regression models of labile carbon with microbial biomass carbon $\left(R^{2}=0.8946\right)$ and with soil respiration $\left(R^{2}=\right.$ 0.9053) were significant and with a good fit.

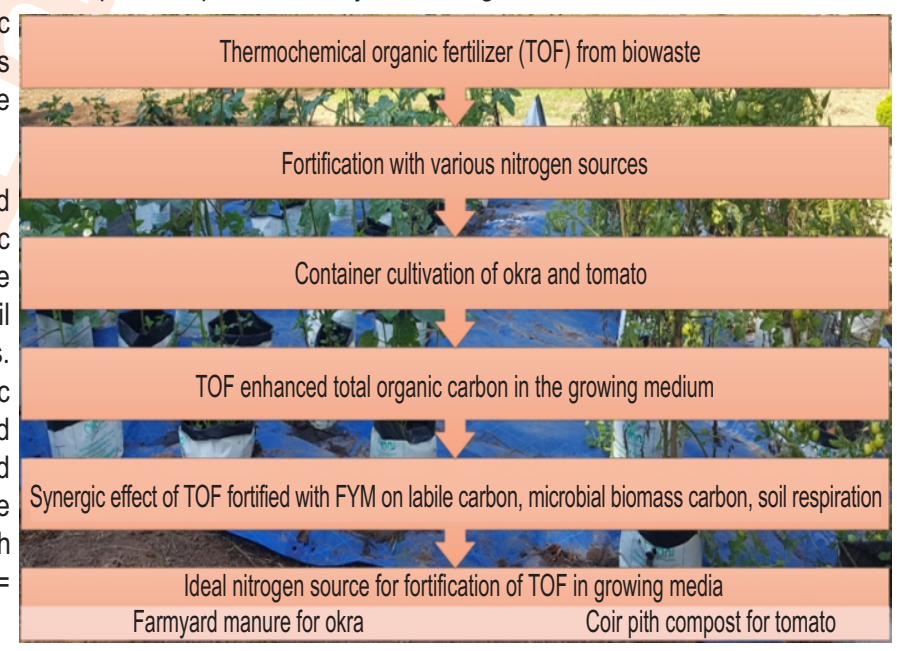

Interpretation: Fortification of thermochemical organic fertilizer with various organic sources of nitrogen imparted a high total soil organic carbon status. Synergic effect of the farmyard manure fortification was evident in labile carbon, microbial biomass carbon and soil respiration. Growing media fortified with farmyard manure was ideal for container cultivated okra whereas that with coir pith proved to be ideal for tomato, a solanaceous vegetable crop.

Key words: Carbon respiration, Container cultivation, Growing media, Labile carbon, Microbial biomass

How to cite : Leno, N., G. Jacob, J. Jayakrishna, S.R. Kavya, M.K. Krishnapriya, L. Taki, M.M. Sreelakshmi, M.R. Rehana and A.B. Vijay: Carbon fractions of fortified thermochemical organic fertilizers and their response on the yield of okra and tomato. J. Environ. Biol., 42, 1544-1553 (2021). 


\section{Introduction}

The global solid waste generation is projected to reach 3539 million tonnes by 2050 (Chen et al., 2020). This is compounded by rapid urbanization and consequent accelerated consumeristic preferences owing to a booming economy of scale (Tun and Juchelkova, 2018). About $60-80 \%$ of the municipal solid waste comprise of degradable materials with essential nutrient content, especially carbon (Ramachandra et al., 2018; Samah et al., 2018). Soil organic carbon is one of the widely used soil quality indicators along with $\mathrm{pH}$ and available $\mathrm{P}$ and $\mathrm{K}$ (Bunemann et al., 2018). Depletion of soil organic carbon particularly in the tropical soils results in deterioration of productive gains from crop cultivation (Sayer et al., 2019). Agronomic technological and management practices aiming at increasing the soil organic carbon stocks are gaining global attention (Bongiorno et al., 2019). Technological options for waste disposal at source after processing and recycling as organic manure would be a feasible solution (Jouhara et al., 2017; Abdel-Shafy and Mansour, 2018).

Different fractions of carbon in the soil organic carbon pool are of much significance (Sandeep et al., 2016; Leno, 2020). The potassium permanganate extractable labile carbon fraction has a relatively lesser residence time and is easily disintegrated (Ramesh et al., 2019). The labile carbon fractions serve as indicators of various soil functions (Bongiorno et al., 2019). The soil microorganisms use it as a primary source of energy for their growth and development (Chantigny, 2003; Haynes, 2005). The microbial biomass carbon represents the living component of soil organic matter (Prasanthi et al., 2017). Decline in microbial biomass occurs due to decrease in plant carbon input (Fierer et al., 2009). Soil respiration may involve respiration by the plant roots, rhizospheric environment, microbes and soil fauna (Kukumagi et al., 2017).In soil, nitrogen is mobilized from soil organic matter to pools more readily available to plants, mediated by microbial biomass. Multiple mechanisms underpin this process, including the priming effect which is increasingly recognized as an important driver of nitrogen mineralization. Understanding these alterations in carbon and nitrogen cycles is essential to set up sustainable management practices in agro-ecosystems to effectively counteract the progressive loss of organic matter returns and soil organic matter contents (Kochsiek and Knops, 2012).

The patented rapid thermochemical biowaste processing technology (Sudharmaidevi et al., 2017) enables processing of solid waste to organic fertilizer in less than a day in an environment friendly manner. Container cultivation of vegetables is gaining much acclaim in urban and semi-urban households where per capita land availability is much less. Thermochemical organic fertilizer based growing media can be utilized for container cultivation of vegetables in growing bags and pots. Container cultivated tomato in a growing medium comprising of thermochemical organic fertilizer, coco peat and top soil significantly out yielded those grown in conventional growing media of top soil, sand and farmyard manure (Jayakrishna et al.,
2016). The efficiency of thermochemical organic fertilizer on growth and yield of vegetables and banana has been confirmed in several studies conducted at the Kerala Agricultural University (Jayakrishna et al., 2016; Leno and Sudharmaidevi, 2017; Ramesha, 2019). The carbon content in thermochemical organic fertilizer is considered to be superior in imparting an enhanced rhizosphere priming effect as compared to conventional organic manure sources (Jacob, 2018).

The rhizosphere priming effect is decisively linked with carbon and nitrogen dynamics largely contributed by the added thermochemical organic fertilizer. The efficiency of thermochemical organic fertilizer in providing a synchronous supply of essential nutrients inclusive of micronutrients during the critical growth stages of banana has been well established (Leno et al., 2017; Leno and Sudharmaidevi, 2018). The inherently acidic soils of Kerala are predominantly deficient in secondary nutrient elements calcium and magnesium. Deficiencies of micronutrients zinc and boron have also been reported extensively (Nair et al., 2013), hence, for maintaining crop production at sustainable levels, the thermochemical organic fertilizer needs to be fortified with mineral supplements for essential nutrients, which are present in very small quantity, particularly nitrogen which is significant in promoting the soil microbial population. It is indispensable for maintaining soil health and quality. Microbial proliferation in soil is also particularly linked with different fractions of soil organic carbon. Hence, the fractional contents of added thermochemical organic fertilizer are of much relevance. The present study was undertaken to characterize various carbon fractions in thermochemical organic fertilizer fortified with various sources of nitrogen and to identify the most suitable nitrogen source for fortifying thermochemical organic fertilizer in terms of yield response of container cultivated okra and tomato using fortified thermochemical organic fertilizer based potting mixture.

\section{Materials and Methods}

The biodegradable waste collected from the students' hostel of the College of Agriculture, Trivandrum was subjected to thermochemical decomposition by the patented rapid waste processing technology developed at the Kerala Agricultural University (Sudharmaidevi et al., 2017). The biowaste was ground to a homogenous paste and subjected to thermochemical processing for $1 \mathrm{hr}$ at $100^{\circ} \mathrm{C}$ during which two reagents were added at an interval of $0.5 \mathrm{hr}$. Coir pith $(3 \%)$ was added to the digestate, dried and fortified. The organic fertilizer was fortified with seven different organic sources of nitrogen added on a nitrogen equivalent basis of $1 \%$. Farmyard manure $(0.826 \mathrm{~kg})$, neem cake $(0.446 \mathrm{~kg})$, groundnut cake $(0.147 \mathrm{~kg})$, poultry manure $(0.420 \mathrm{~kg})$, vermicompost $(0.446 \mathrm{~kg})$, coir pith compost $(0.990 \mathrm{~kg})$ and hatchery waste organic fertilizer $(0.192 \mathrm{~kg})$ were addedto one $\mathrm{kg}$ of TOF. The chemical characteristics of these organic manures and thermochemical organic fertilizer are outlined in Table 1. A pot culture experiment was conducted at the College of Agriculture, Vellayani which is classed under agro-ecological unit 
(AEU) 8 in Thiruvananthapuram district of Kerala (Fig.1) in the year 2019 to study the yield response of okra var Anjitha and tomato va $r$ Anagha to thermochemical organic fertilizer (TOF) fortified with various sources of nitrogen. The design used was a completely randomised design with nine treatments and three replications. The plants were raised in grow bags filled with growing medium upto $213^{\text {rd }}$ capacity. The growing medium comprised of top soil, coir pith and fortified TOF mixed in 1:1:1 (vlv) ratio. Fortification of thermochemical organic fertilizer was done with farmyard manure (TOF+FYM); neem cake (TOF+NC); groundnut cake $(\mathrm{TOF}+\mathrm{GC})$; poultry manure (TOF+PM); vermicompost (TOF+VC); coir pith compost (TOF+CPC); and hatchery waste organic fertilizer (TOF+HWOF).A treatment of thermochemical organic fertilizer fortified with urea $(0.0217 \mathrm{~kg}$ in one $\mathrm{kg}$ of TOF), fertilizer nitrogen (46\%) source was also included. An unfortified thermochemical organic fertilizer treatment (TOF) was taken as control.

The soil used for growing medium preparation was classified as clayey, kaolinitic, isohyperthermic, Typic kandiustults of Vellayani series which exhibited moderately acidic $\mathrm{pH}$ (5.5), safe electrical conductivity $\left(0.20 \mathrm{dS} \mathrm{\textrm {m } ^ { - 1 }}\right)$, low in organic carbon content $(0.42 \%)$ and available nitrogen (163.07 kg ha $\left.{ }^{-1}\right)$, high in available phosphorus (59.08 $\left.\mathrm{kg} \mathrm{ha}^{-1}\right)$ and medium in available potassium $\left(190.40 \mathrm{~kg} \mathrm{ha}^{-1}\right)$. The soil was deficient in secondary nutrients calcium (160 mg kg-1) and magnesium $\left(50 \mathrm{mg} \mathrm{kg}^{-1}\right)$ and micronutrients copper $\left(0.38 \mathrm{mg} \mathrm{kg}^{-1}\right)$ and boron $\left(0.54 \mathrm{mg} \mathrm{kg}^{-1}\right)$. The coir pith used for growth medium preparation had a $\mathrm{pH}$ of 6.2 , electrical conductivity of $5.65 \mathrm{dS} \mathrm{m}^{-1}$, organic carbon content $(12.7 \%)$, total nitrogen $\left(10.1 \mathrm{~g} \mathrm{~kg}^{-1}\right)$, total phosphorus $\left(0.7 \mathrm{~g} \mathrm{~kg}^{-1}\right)$, total $\mathrm{K}\left(12.5 \mathrm{~g} \mathrm{~kg}^{-1}\right)$, total calcium $\left(8.0 \mathrm{~g} \mathrm{~kg}^{-1}\right)$, total magnesium $(7.0$ $\left.\mathrm{g} \mathrm{kg}^{-1}\right)$, total iron (4585 mg kg-1), total manganese $\left(61.7 \mathrm{mg} \mathrm{kg}^{-1}\right)$, total zinc $\left(56 \mathrm{mg} \mathrm{kg}^{-1}\right)$, total copper $\left(40.6 \mathrm{mg} \mathrm{kg}^{-1}\right)$ and total boron $\left(1.7 \mathrm{mg} \mathrm{kg}^{-1}\right)$.

Carbon fractional analysis: Samples of growing medium were drawn from each treatment. The total organic carbon (TOC) content of the growing medium of various fortified fertilizers was determined by elementary carbon analysis with combustion $>950^{\circ} \mathrm{C}$ by a Vario El cube, Elementar, CHNS Analyzer, Germany. A $0.02 \mathrm{M} \mathrm{KMnO}_{4}$ oxidisable labile carbon was extracted and analysed following the procedure of Weil et al. (2003). Microbial biomass carbon (MBC) was determined by the method of chloroform-fumigation extraction of Vance et al. (1987), using $0.01 \mathrm{M} \mathrm{CaCl}_{2}$ as extractant and $\mathrm{MBC}$ was calculated as the difference between fumigated and non fumigated samples, with conversion factors of 0.45 for incomplete extraction of microbial carbon. To assess basal soil respiration (SR), moist samples (approx. $60 \%$ of $\mathrm{WHC}$ ) were incubated at $25^{\circ} \mathrm{C}$ for $72 \mathrm{hr}$ in a thermostat bath. The $\mathrm{CO}_{2}$ rate was determined when it stabilized at $72 \mathrm{hr}$ from the beginning of the incubation. The evolution of $\mathrm{CO}_{2}$ gas was assessed by alkali trap followed by titrimetry (Brewer and Sullivan, 2003).

Yield and fruit characters: The matured fruits of tomato were harvested when the fruits turned slight yellowish in color. Four harvests were done at $60,66,73$ and 85 days after planting. The total number of fruits and weight of fruits of each plant were recorded. The pods of okra were harvested at tender and immature stage. Four harvests were done at $63,74,83$ and 91 days after planting. The total number of pods, length and girth of pods and pod weight of each plant were recorded.

Statistical analysis: The data of pot culture study was analysed statistically by applying analysis of variance. The $F$ values for treatments were compared with the table values. If the effects were significant, critical differences at $5 \%$ significance level were calculated for effecting comparison among the means. Data analytical package Web Agri Stat Package (WASP) ver.2.0 was used for data analysis.

\section{Results and Discussion}

Growing media prepared with thermochemical organic fertilizer fortified with farmyard manure exhibited the highest total organic carbon content of $44.06 \mathrm{~g} \mathrm{~kg}^{-1}$ among the various nitrogen sources that were employed for fortification (Fig. 2a). This may be ascribed to the higher relative proportion of farmyard manure that was utilized for fortification owing to the comparatively lower inherent content of nitrogen in it. Poultry manure and groundnut cake, with their inherently higher proportion of nitrogen content in comparison with other organic manure sources contributed to relatively lower total organic carbon content. All fortification combinations involving organic manure sources registered a

Table 1: Chemical characteristics of the thermochemical organic fertilizer and the organic sources of nitrogen used for fortification

\begin{tabular}{|c|c|c|c|c|c|c|}
\hline Manure & $\mathrm{pH}$ & $\begin{array}{l}\text { TOC } \\
\left(\mathrm{g} \mathrm{kg}^{-1}\right)\end{array}$ & $\begin{array}{l}N \\
\left(g_{k g}{ }^{-1}\right)\end{array}$ & $\begin{array}{l}P \\
\left(g_{k g}{ }^{-1}\right)\end{array}$ & $\begin{array}{l}K \\
\left(g_{k g}^{-1}\right)\end{array}$ & $\mathrm{C}: \mathrm{N}$ ratio \\
\hline Farmyard manure & 6.19 & 400.00 & 12.10 & 10.10 & 4.01 & 30.53 \\
\hline Neem cake & 7.12 & 433.20 & 22.40 & 5.70 & 10.30 & 19.34 \\
\hline Groundnut cake & 7.09 & 463.70 & 68.01 & 1.41 & 1.14 & 6.82 \\
\hline Poultry manure & 6.76 & 228.40 & 23.80 & 10.20 & 11.21 & 9.60 \\
\hline Vermicompost & 5.57 & 242.80 & 22.44 & 11.10 & 15.23 & 10.84 \\
\hline Coir pith compost & 6.21 & 127.38 & 10.12 & 0.07 & 12.50 & 12.61 \\
\hline Hatchery waste organic fertilizer & 7.06 & 280.00 & 52.21 & 0.12 & 0.09 & 5.36 \\
\hline Thermochemical organic fertilizer & 6.80 & 392.90 & 21.83 & 9.30 & 14.51 & 18.02 \\
\hline
\end{tabular}


Table 2: Effect of treatments on yield and yield components of okra

\begin{tabular}{lllll}
\hline Treatments & Yield $\left(\right.$ g plant $\left.{ }^{-1}\right)$ & Fruit length $(\mathbf{c m})$ & Fruit girth $(\mathbf{c m})$ & Total fruits $($ nos) \\
\hline TOF & $251.69^{\mathrm{ab}}$ & $14.10^{\mathrm{cd}}$ & 5.70 & $10.00^{\mathrm{a}}$ \\
TOF+FYM & $267.44^{\mathrm{a}}$ & $20.60^{\mathrm{a}}$ & 6.44 & $11.67^{\mathrm{a}}$ \\
TOF+NC & $110.56^{\mathrm{c}}$ & $16.61^{\mathrm{bcd}}$ & 6.00 & $3.00^{\mathrm{c}}$ \\
TOF+GC & $156.69^{\mathrm{c}}$ & $15.11^{\mathrm{bcd}}$ & 5.99 & $4.67^{\mathrm{cc}}$ \\
TOF+PM & $189.59^{\mathrm{abc}}$ & $17.99^{\mathrm{ab}}$ & 6.35 & $5.67^{\mathrm{cc}}$ \\
TOF+VC & $147.07^{\mathrm{c}}$ & $16.05^{\mathrm{bcd}}$ & 6.33 & $4.67^{\mathrm{bc}}$ \\
TOF+CPC & $190.11^{\mathrm{abc}}$ & $13.90^{\mathrm{d}}$ & 6.06 & $8.00^{\mathrm{ab}}$ \\
TOF+HWOF & $137.20^{\mathrm{c}}$ & $20.68^{\mathrm{a}}$ & 5.79 & $4.33^{\mathrm{bc}}$ \\
TOF+U & $171.47^{\mathrm{bc}}$ & $17.16^{\mathrm{bc}}$ & 5.73 & $6.00^{\mathrm{bc}}$ \\
\hline
\end{tabular}

TOF: Thermochemical organic fertilizer (unfortified); FYM: Farmyard manure; NC: Neem cake; GC: Groundnut cake; PM: Poultry manure; VC: Vermicompost; CPC: Coir pith compost; HWOF: Hatchery waste organic fertilizer; U: Urea. Mean between treatments followed by different letters are significantly different at $5 \%$ level.

Table 3: Effect of treatments on yield and number of fruits in tomato

\begin{tabular}{lll}
\hline Treatments & $\begin{array}{l}\text { Yield } \\
\text { (g plant }^{-1} \text { ) }\end{array}$ & $\begin{array}{l}\text { Total fruits } \\
\text { (nos) }\end{array}$ \\
\hline TOF & $265.00^{\mathrm{c}}$ & $14.00^{\mathrm{b}}$ \\
TOF+FYM & $228.90^{\text {cd }}$ & $15.00^{\mathrm{b}}$ \\
TOF+NC & $150.31^{\mathrm{d}}$ & $12.67^{\mathrm{b}}$ \\
TOF+GC & $422.02^{\mathrm{b}}$ & $24.33^{\mathrm{a}}$ \\
TOF+PM & $255.12^{\mathrm{c}}$ & $11.33^{\mathrm{b}}$ \\
TOF+VC & $196.54^{\text {cd }}$ & $10.00^{\mathrm{b}}$ \\
TOF+CPC & $537.53^{\mathrm{a}}$ & $24.67^{\mathrm{a}}$ \\
TOF+HWOF & $252.45^{\mathrm{c}}$ & $16.00^{\mathrm{b}}$ \\
TOF+U & $188.62^{\text {cd }}$ & $15.00^{\mathrm{b}}$ \\
\hline
\end{tabular}

TOF: Thermochemical organic fertilizer (unfortified); FYM: Farmyard manure; NC: Neem cake; GC: Groundnut cake; PM: Poultry manure; VC: Vermicompost; CPC: Coir pith compost; HWOF: Hatchery waste organic fertilizer; U: Urea. Mean between treatments followed by different letters are significantly differentat $5 \%$ level.

higher total organic carbon content than the urea based fortification treatment with the coir pith compost based fortification registering a $64.95 \%$ increase over the urea based fortification treatment. This unequivocally substantiates the crucial role of organic manures, irrespective of the source of origin, whether based on animals, birds, earthworms, oil cakes, composts or thermochemical processing, in augmenting and maintaining the soil organic carbon content at sustainable levels. In a long term fertilizer experiment spanning twenty years, unlike in NPK treatments, application of organic fertilizers alone resulted in the enhancement of total soil organic carbon from $8 \mathrm{~g} \mathrm{~kg}^{-1}$ to $16 \mathrm{~g} \mathrm{~kg}^{-1}$ indicating the significant effect of organic fertilizer in the red soils at Qiyang County, Hunan Province, China (Wang et al., 2019).

Growing media containing fortified urea recorded the lowest organic carbon content of $11.87 \mathrm{~g} \mathrm{~kg}^{-1}$. Urea being a high analysis fertilizer with $46 \%$ nitrogen required to be added in relatively lesser quantity, while undergoing fortification. Further, the loss of carbon content due to urea hydrolysis may also occur in the growing media prepared in accordance with this treatment. The $\mathrm{CO}_{2}$-C emission factor from urea is estimated to be $0.2 \mathrm{Mg} \mathrm{C}$ per mg urea applied to the field (Kim et al., 2016). The permanganate oxidisable labile carbon fraction is of paramount importance in enhancing soil quality. Growing media prepared with fortification treatments based on farmyard manure and vermicompost recorded the highest labile carbon content among the nine treatments (Fig. 2b). Leno (2021) highlighted the meritorious benefit of labile carbon dynamics of thermochemical organic fertilizer in imparting a positive effect in the banana grown Ultisols of agro-ecological unit 8 , a pedoclimatic soil classification of Southern laterites. Thermochemical organic fertilizer based growing media prepared by fortification with farmyard manure enhanced labile carbon by $9.74 \%$ and with vermicompost by $7.36 \%$ over thermochemical organic fertilizer used without fortification. Hence, the present finding brings to light the positive synergistic effect brought about by the supplementary addition of thermochemical organic fertilizer with farmyard manure and vermicompost in enhancing the labile carbon content of growing medium in container cultivation. The relatively lower labile carbon content exhibited by fortification treatments with poultry manure, hatchery waste organic manure and groundnut cake may be ascribed to high nitrogen content as compared to other organic manure sources, thus requiring only lesser quantities to be added for fortification. However, the labile carbon content of all these sources were superior to the fertilizer urea fortified treatment, which yielded the lowest labile carbon content $\left(967 \mathrm{mg} \mathrm{kg}^{-1}\right)$.

Soil health is largely dependent on the quantity and intensity of soil microbial population, which is the centre stage of soil biological activity. Soil microbes are a crucial component in a large number of ecosystem processes, which include decomposition, nutrient acquisition, carbon and nitrogen cycling as well as soil formation and carbon sequestration (Gessner et al., 2010; Rillig and Mummey, 2006; Six et al., 2006; Sun et al., 2021). The soil microbial biomass carbon is a measure of the turnover of soil microbial load present in the soil. The soil microbes utilize and gain energy from the soil carbon compounds. Invariably it is the 

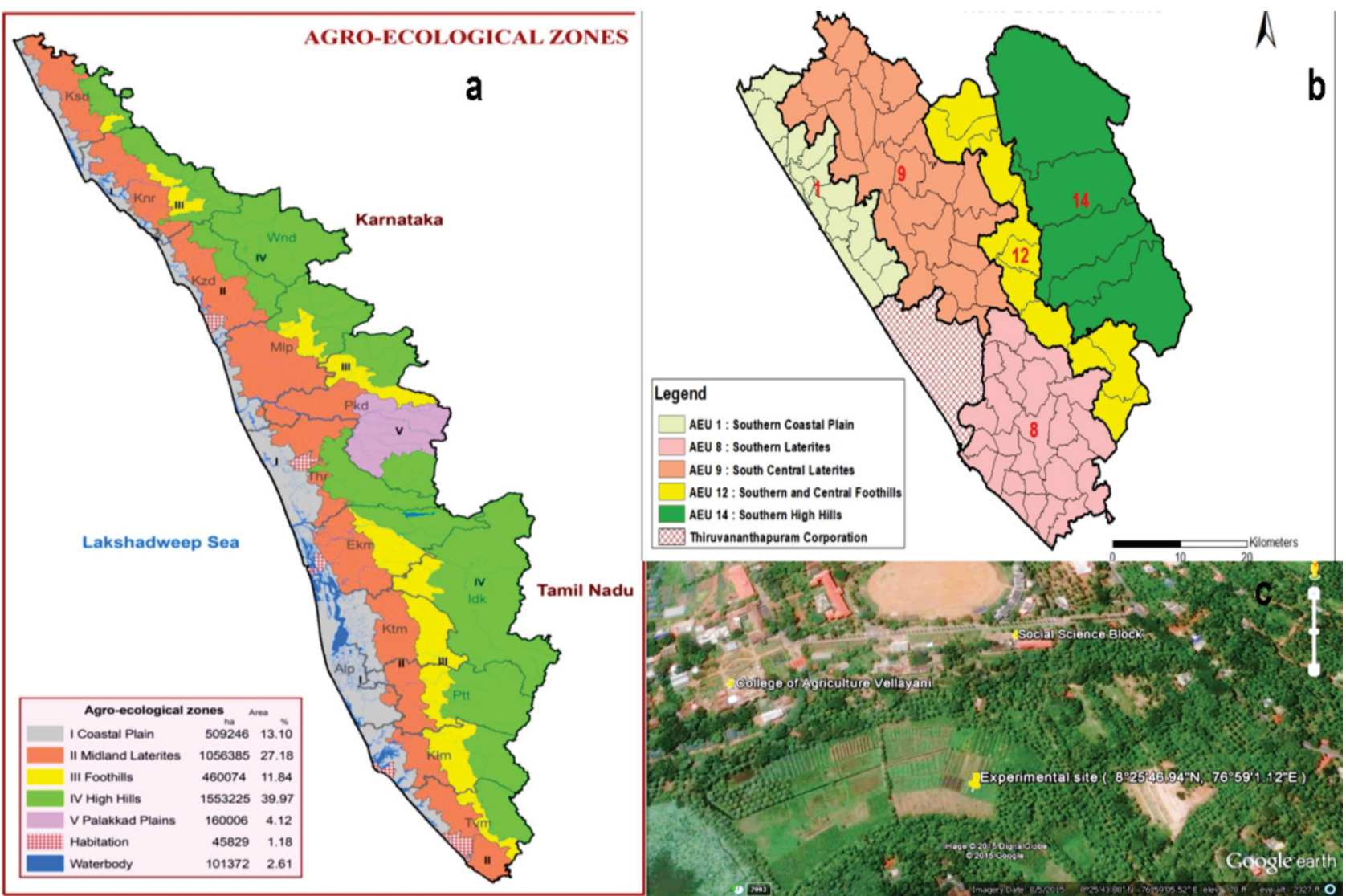

Fig. 1: Maps depicting the district wise agro ecological zones of Kerala (a), agro ecological units (AEU) of Thiruvananthapuram district (b) and imagery of the experimental site located in AEU 8 (c).

labile carbon fraction consisting of simple sugars and amino acids that have a lesser residence time in soil and form an amenable substrate for the proliferation of microbes (Chatterjee et al., 2021; Yanardag et al., 2017). Growing media prepared with fortified thermo-chemical organic fertilizer with farmyard manure and unfortified thermochemical organic fertilizer recorded the highest microbial biomass carbon of $1.33 \mu \mathrm{g} \mathrm{g}^{-1}$ (Fig. 2c). While the former treatment registered an enhancement of $19.82 \%$, the latter registered an increment of $16.32 \%$ over the fortified thermochemical organic fertilizer with vermicompost. The microbial biomass carbon estimated from the other organic sources of nitrogen fortification though lower was superior to the growing media prepared with fortification of thermochemical organic fertilizer with urea fertilizer. Pan et al. (2009) demonstrated that application of manure increased the soil microbial biomass carbon by $13 \%$ as compared to application of mineral fertilizer.

This emphasizes the supremacy of the organic fertilizers over inorganic fertilizers in effecting a positive response to soil microbial biomass content. The carbon dioxide carbon, the form in which carbon is evolved by way of soil respiration which encompasses carbon dioxide evolved from the entire rhizosphere which comprises of the soil, microbes, plant roots and other constituents. The drivers of soil respiration can be classed as physical processes and soil biogeochemical properties. The carbon dioxide carbon evolved in the growing media with thermochemical organic fertilizer fortified with farmyard manure was the foremost registering a $6.98 \%$ increase over the treatment fortified with vermicompost (Fig. 2d).

The high total carbon content observed in this treatment might have contributed to improving the soil physical properties, better soil aggregation, decreased bulk density, improved porosity ultimately enabling aeration and respiration. Surface area of aggregates exposed to microorganisms increased with increasing proportion of aggregates $<1.0 \mathrm{~mm}$ (Liebig et al., 1995). Therefore, with aggregation being favored with an increase in the proportion of aggregates $<1.0 \mathrm{~mm}$, the soil physical environment may have become congenial for fungal activity. It is predominantly the fungi which contribute more to carbon mineralization as they generally predominate the microbial biomass in most soils. The superior microbial biomass carbon content evidenced in this treatment bears testimony to the favourable microbial 

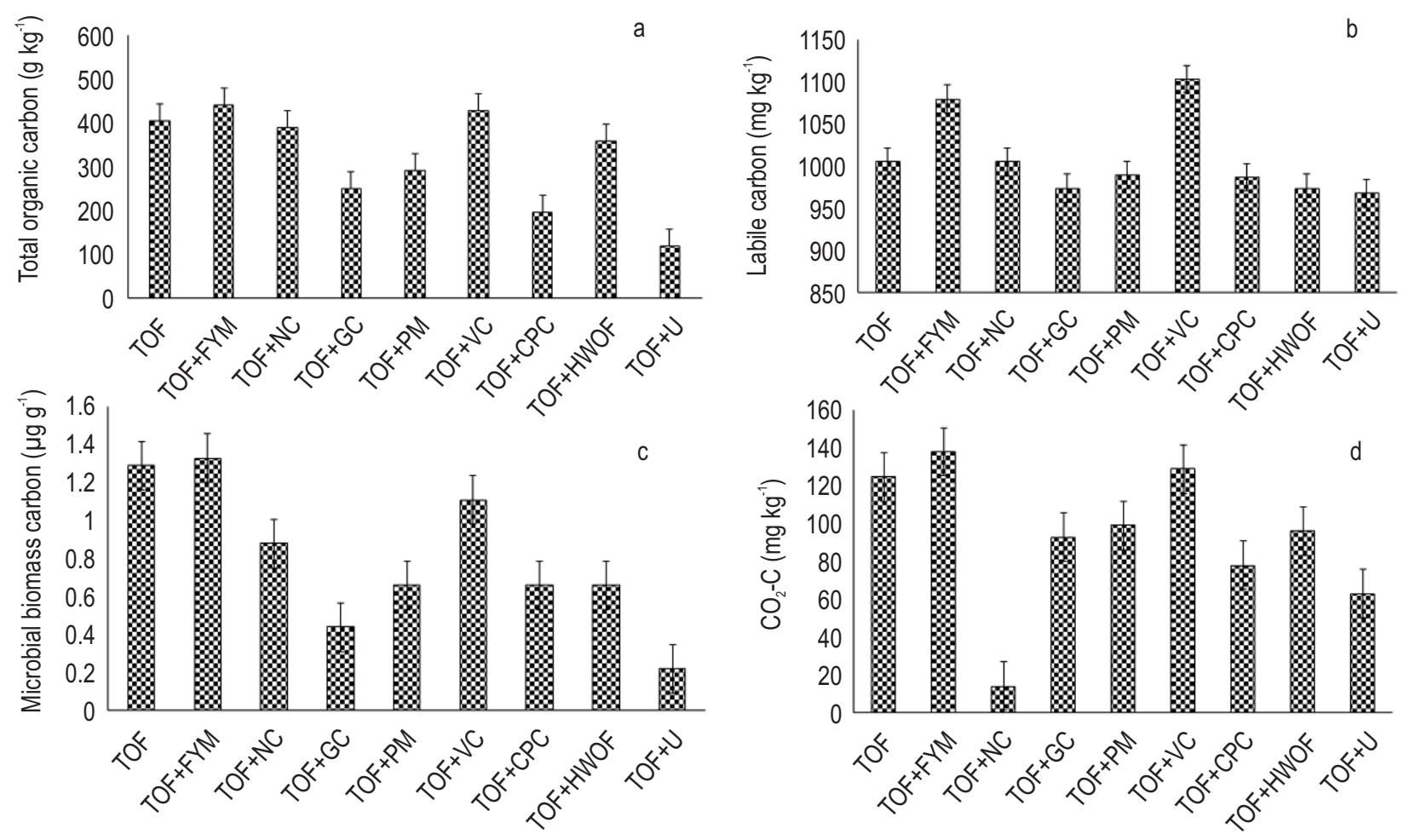

Fig. 2: Status of organic carbon fractions of growing media with thermochemical organic fertilizers fortified with different nitrogen sources. TOF: Thermochemical organic fertilizer (unfortified); FYM: Farmyard manure; NC: Neem cake; GC: Groundnut cake; PM: Poultry manure; VC: Vermicompost; CPC: Coir pith compost; HWOF: Hatchery waste organic fertilizer; U: Urea. Error bars indicate standard deviation.

proliferation facilitated by the high labile carbon fraction registered in this treatment. The oxidation of permanganate oxidisable labile carbon mimics microbial decomposition of organic matter, which is confirmed by its often positive correlation with basal respiration, substrate -induced respiration, microbial biomass and soluble carbohydrates (Weil et al., 2003). Though fortification with other organic manure sources studied liberated more amount of carbon dioxide carbon than the urea fortified treatment, the urea treatment liberated higher amounts of carbon dioxide carbon than the neem cake fortified treatment. This may be attributed to the hydrolysis of urea which might have liberated carbon dioxide.

The container grown okra in a growing media with one of its three constituents being thermochemical organic fertilizer fortified with farmyard manure yielded the highest number of fruits which was on par with the unfortified thermochemical organic fertilizer (Table 2). Considering the fruit characters, the same treatment recorded the highest fruit length $(20.60 \mathrm{~cm})$ which was on par with the hatchery waste organic fertilizer. However no significant difference existed among the different treatments with regard to fruit girth. The significantly higher number of total fruits and the highest fruit length might have contributed to this treatment resulting in the highest plant yield ( $\left.267.44 \mathrm{~g} \mathrm{plant}^{-1}\right)$ as compared to organic and inorganic nitrogenous sources of fortification. There was a yield increase of $6.26 \%$ from that obtained for unfortified thermochemical organic fertilizer and a $55.96 \%$ increment over the treatment with urea fertilizer fortification. Thermochemical organic fertilizer, the principal constituent in the growing media of the superior treatment as well as farmyard manure, the supplementary constituent used for fortification had a comparatively high total organic carbon content of $392.9 \mathrm{~g} \mathrm{~kg}^{-1}$ and $400.0 \mathrm{~g} \mathrm{~kg}^{-1}$ respectively.

The presence of plants alone or in combination with organic manures induces priming effects. The direction and magnitude of this rhizosphere priming have been related to soil nutrient availability, here the nutrient composition of growing media. Under low nutrient availability, particularly nitrogen inputs of energy-rich carbon compounds from roots may be used for the production of extra-cellular enzymes that can release nutrients locked in soil organic matter referred as microbial mining which enhances the availability of other nutrients for plant growth and is mainly measured in terms of $\mathrm{CO}_{2}$ release (Brzostek et al., 2012: Fontaine et al., 2012). The synergistic effect brought about by the resultant carbon and nitrogen dynamics might have favored the enhanced yield of okra crop. The high content of labile carbon in this growing media in comparison with other fortification treatments might have ensured easily available carbon substrate for the proliferation of rhizospheric microbes. The high microbial 

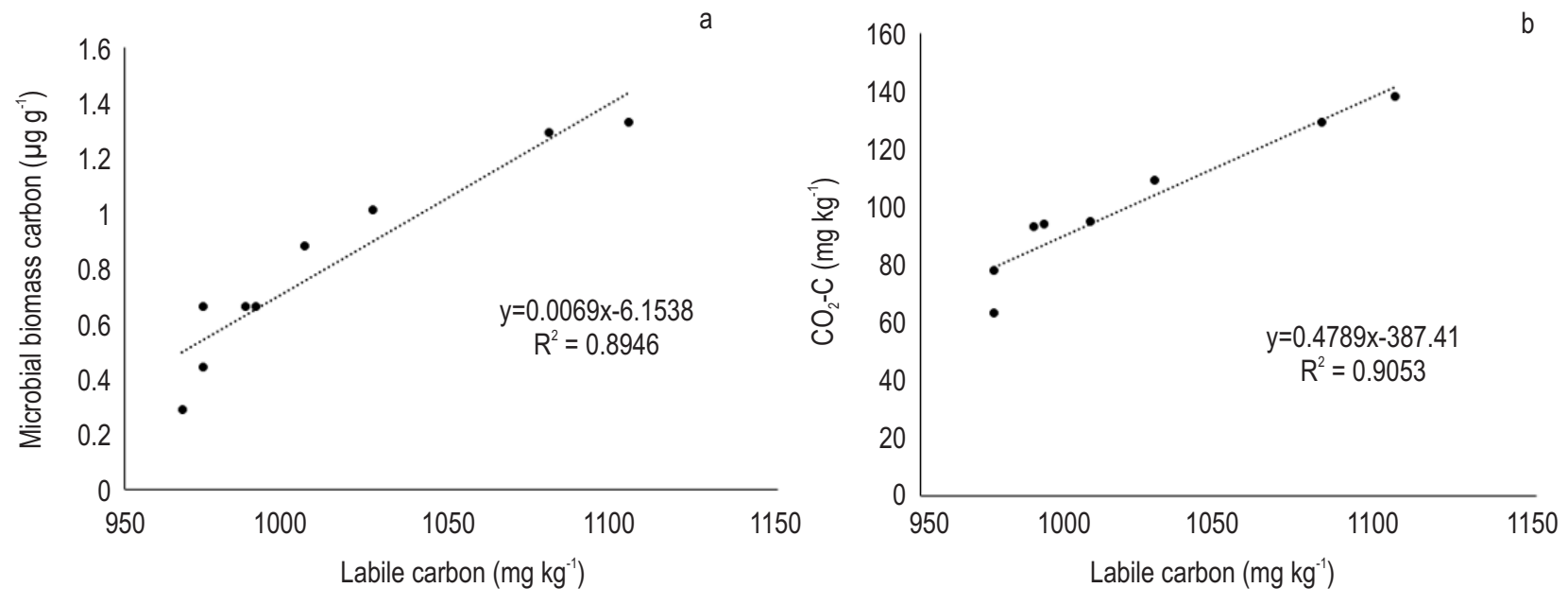

Fig. 3: Relationship between labile carbon with microbial biomass carbon and soil respiration in growing media with fortified thermochemical organic fertilizers.

biomass carbon $\left(1.33 \mu \mathrm{g} \mathrm{g}^{-1}\right)$ observed in this growing medium is in further confirmation of the enhanced microbial population which might have promoted efficient mineralization of nutrients. The thermochemical organic fertilizer-farmyard manure combination might have induced a positive priming effect in carbon and nitrogen mineralization. The fast turnover of labile carbon and microbial activity in the rhizosphere tend to alter the rate of decomposition of soil organic matter, which is reflected in enhanced root activity (Jacob, 2018). A parallel increase in the evolution of carbon dioxide carbon obtained for the same treatment in the present study is in perfect justification of this fact. The turnover rate of labile carbon fraction decides the nutrient dynamics and the soil physical factors, especially soil structure (Bongiorno et al., 2019). Three types of binding agents viz. transient, temporary and persistent binding agents act in the formation of soil structure. The high labile carbon in the growing media of thermochemical organic fertilizer fortified with farmyard manure denotes that it has a high quantity of transient binding agents like extra cellular mucilages or gums produced by microbial activity and root exudates.

The liberation of carbon dioxide carbon, an indication of soil respiration can also be effected by the positive effects brought about with regard to soil physical and biological properties which might have catalyzed efficient root nutrient acquisition and uptake by the plant. This might have facilitated a better translocation of photosynthate to the above ground and below ground parts of the plant. The high soil respiration recorded for this treatment is a reflection of this effect. Fresh carbon supplies from the photosynthate govern the bulk of soil respiration (Balogh et al., 2011; Ning et al., 2021). The efficient supply and translocation of photosynthate have led to a higher yield in the farmyard manure fortified thermochemical organic manure based growing media treatment. The response of container grown tomato in growing media prepared with thermochemical organic fertilizer fortified with different sources of nitrogen was not similar to that of okra and exhibited marked variation. Unlike in okra, the total number of fruits per plant and the yield per plant was superior in the growing media treatment constituted by thermochemical organic fertilizer fortified with coir pith compost as one of the constituents (Table 3). The additional increment in yield obtained for the coir pith compost treatment as compared to the groundnut cake fortified growing media was $27.37 \%$ and that over the unfortified thermochemical organic fertilizer based treatment was $102.84 \%$.

The near neutral $\mathrm{pH}$ of the coir pith compost might have enabled constant supply of available nutrients to the plant roots which facilitated a better growth rate. At near neutral $\mathrm{pH}$, the medium will be abundant with substances appropriate for plants to assimilate and contains sufficient humus and microorganisms (Sarauskis et al., 2018). The C:N ratio of the coir pith compost (12.61) used for fortification, which is near to that of the ideal C:N ratio might have created a triggering mechanism, ensuring the optimum levels of the kind and intensity of rhizospheric microbes. The resultant favourable biochemical environment might have facilitated better root nutrient acquisition and translocation of nutrients within the plant. The dry matter accumulation during the initial 30 days in tomato is lessthan $5 \%$ which then increase linearly up to 90 days (Abreu et al., 2018).

The ideal anion and cation ratio for tomato was found to be 58:36:6 for N:S:P and 39:32:29 for K:Ca:Mg (Olaniyi and Ajibola 2008). Tomato is capable of utilizing only a small percentage of the inorganic nitrogen available in the large volume of soil explored by the roots (Hegde, 1997). In studies with labelled carbon and nitrogen, Ge et al., 2009 observed that about $21 \%$ of the supplied glycine- $\mathrm{N}$ was taken up in the form of intact amino acids by tomatoes within $48 \mathrm{~h}$ after injection into the soil. 
The prolonged and sustained decomposition of the lignocellulosic organic fraction of the coir pith compost, aided by the lignocellulytic fungi might have effected a supply of organic amino acid forms of carbon, nitrogen and other nutrients to the tomato crop synchronous with the critical demand period of the crop, particularly during the fruit ripening phase. Tomato has the greatest requirement of $\mathrm{K}, \mathrm{N}, \mathrm{Ca}$ and $\mathrm{P}$ just before the fruit begins to ripen (Al Mohammadi and Al Zu, 2011; Ramesh et al.,2021).

The efficient translocation of photosynthate to the fruits enabling a partitioning of vegetative biomass to reproductive biomass might have been facilitated. This allocative efficiency subsequently resulted in a higher fruit yield. Chaurasia et al. (2012)observed that $45.8-59.2 \% \mathrm{~N}, 56.5-63.6 \% \mathrm{P}$ and $62-69.6 \%$ $\mathrm{K}$ of the total nutrient uptake was partitioned into the fruit. Substrates that have a low C:N ratio contain relatively high concentrations of ammonia, exceeding concentrations necessary for microbial growth and a higher $\mathrm{C}$ : $\mathrm{N}$ ratio reduced the protein solubilisation rate and hence produced lower total ammoniacal nitrogen and free ammonia concentration (Wang et al., 2014). Moreover in case of growing media fortified with coir pith compost where the nitrogen content is very low $\left(10.1 \mathrm{~g} \mathrm{~kg}^{-1}\right.$ of compost), the exudates might be used to enhance organic matter decomposition rates thus releasing nutrients available for plant uptake, resulting in higher yields. The yield obtained for the urea fortification treatment (188.62 g plant $\left.{ }^{-1}\right)$ is only higher to the lowest yield recorded neem cake fortified treatment and might have promoted a higher and luxuriant shoot growth. Jayakrishna et al., 2016 observed that a growing medium consisting of soil, coir pith compost/ coir pith and thermochemical organic resulted in the highest concentration of all essential macro and micronutrients in the shoot and fruit and gave the highest fruityield in container grown chili. Thus the response of tomato to coir pith compost fortification based growing media, obtained in the present study, is an indication of being ideal for solanaceous crops. Simple linear regression models were fitted between the labile carbon fractions of various growing media constituted with thermochemical organic fertilizer fortified with different manurial sources of nitrogen with the microbial biomass carbon and the soil respiration.

The linear regression model was found to be significant and positive for labile carbon content and microbial biomass carbon $\left(R^{2}=0.8946\right)$ with a good fit (Fig. 3a). This is a further confirmation of the rhizospheric microbial proliferation facilitated by the labile carbon fraction of the growing media. The linear regression model between the labile carbon fraction with soil respiration was also found to be significant and positive $\left(R^{2}=\right.$ 0.9053 ) with a good fit (Fig. 3b). This squarely justifies the positive effect of labile carbon fraction in imparting desirable physical attributes to the soil forbetter aggregation and porosity. It has also helped in enablingf efficient photosynthate translocation to the underground plant parts, a driver of soil respiration. These beneficial effects of labile carbon fraction have ultimately served to realise higher yields in okra and tomato. Irrespective of the organic source of nitrogen used for fortification, the thermochemical organic fertilizer bestowed a high status of total organic carbon to the growing media in container cultivation. Enhancement of carbon status in growing media is an inevitable step towards maintaining soil health and quality and attaining sustainability. Simultaneously, it serves to lock up the carbon favoring soil carbon sequestration preventing emission of carbon dioxide, the potent greenhouse gas. The fractional dynamics of carbon in the added organic matter source is of paramount relevance. The synergic effect of carbon fractions of thermochemical organic fertilizer fortified with farmyard manure in the growing media was quite revealing.

The two pronged meritorious benefit of the permanganate oxidisable labile carbon fraction cannot be belittled. The direct effect of labile carbon in the growing media is addition of organic substrates in an amenable form that would serve to stimulate the microbial biomass. The indirect effect of labile carbon fraction creates a suitable physical environment in the rhizosphere favoring soil respiration. The labile carbon fraction is strongly correlated as a vital driving force for the microbial biomass and as a facilitator of enhanced soil respiration. Growing media with its manurial constituent as thermochemical organic fertilizer fortified with farmyard manure as a nitrogen source proved to be ideal for container cultivated okra whereas that with coir pith as a nitrogen source proved to be ideal for container cultivated tomato.

\section{Acknowledgments}

The authors are grateful to the Associate Director of Research, Regional Agricultural Research Station (Southern Region), Kerala Agricultural University for funding this research program.

\section{Add-on Information}

Authors' contribution: N. Leno: Conceptualization, Supervision, Writing - original draft; G. Jacob: Resources; J. Jayakrishna: Investigation; S. R. Kavya: Writing - review and editing; M. K. Krishnapriya: Methodology; L. Taki: Investigation; M. M. Sreelakshmi: Formal analysis; M. R. Rehana: Formal analysis; A. B. Vijay: Validation.

Research content: The research content of manuscript is original and has not been published elsewhere.

Ethical approval: NotApplicable.

Conflict of interest: The authors declare that there is no conflict of interest.

Data from other sources: NotApplicable.

Consent to publish: All authors agree to publish the paper in Journal of Environmental Biology. 


\section{References}

Abdel-Shafy, H.I. and M.S. Mansour: Solid waste issue: Sources, composition, disposal, recycling, and valorization. Egypt. J. Pet., 27, 1275-1290 (2018).

Abreu,T.B., D.F.H.T. de Oliveira, F.M. de Queiroga, C. Moura, A. Cley, S.L. de Carvalho, M. Tavares and H. Arllen: Accumulation of dry matter and macronutrients by the Caeté tomato under field conditions. DYNA, 85, 101-106 (2018).

Al-Mohammadi, F. and B.Y. Al-Zu: Soil chemical properties and yield of tomato as influenced by different levels of irrigation water and fertilizer. J.Agr. Sci. Tech., 13, 289-299 (2011).

Balogh, J., K. Pintér, S. Fóti, D. Cserhalmi, M. Papp and Z. Nagy: Dependence of soil respiration on soil moisture, clay content, soil organic matter, and $\mathrm{CO}_{2}$ uptake in dry grasslands. Soil Biol. Biochem., 43, 1006-1013 (2011).

Bongiorno, G., E.K. Bünemann, C. U. Oguejiofor, J. Meier, G. Gort, R. Comans, P. Mäder, L. Brussaard and R. de Goede: Sensitivity of labile carbon fractions to tillage and organic matter management and their potential as comprehensive soil quality indicators across pedoclimatic conditions in Europe. Ecol. Indic., 99, 38-50 (2019).

Brewer, L.J. and D.M. Sullivan: Maturity and stability evaluation of composted yard trimmings. Comp. Sci. Util., 11, 96-112 (2003).

Brzostek, E.R., A. Greco, J.E. Drake and A.C. Finzi: Root carbon inputs to the rhizosphere stimulate extra cellular enzyme activity and increase nitrogen availability in temperate forest soils. Biogeochemistry, 12, 98-119 (2012).

Bünemann, E.K., G. Bongiorno, Z. Bai, R.E. Creamer, G. De Deyn, R. de Goede, L. Fleskens, V. Geissen, T.W. Kuyper, P. Mäder and M. Pulleman: Soil quality-A critical review. Soil Biol. Biochem., 120, 105-125 (2018).

Chantigny, M.H.: Dissolved and water-extractable organic matter in soils: a review on the influence of land use and management practices. Geoderma, 113, 357-380 (2003).

Chatterjee, D., A.K. Nayak, A. Mishra, C.K. Swain, U. Kumar, D. Bhaduri, P. Panneerselvam, B. Lal, P. Gautam and H. Pathak: Effect of Long-Term Organic Fertilization in Flooded Rice Soil on Phosphorus Transformation and Phosphate Solubilizing Microorganisms. J. Soil Sci. Plant Nutr., 21, 1368-1381 (2021).

Chaurasia, S.N.S., R.N. Prasad, R.B. Yadava and D. K. Singh: Nutrient Management in Vegetable Crops for Sustainable Production. In: Green Agriculture: Newer Technologies (Eds.: K.K. Behera). New India Publishing Agency, New Delhi, India, pp. 281-302 (2012).

Chen, D.M.C., B.L. Bodirsky, T. Krueger, A. Mishra and A. Popp: The world's growing municipal solid waste: Trends and impacts. Environ. Res. Lett., 15, 1-20 (2020).

Fierer, N., M.S. Strickland, D. Liptzin, M.A. Bradford and C.C. Cleveland: Global patterns in belowground communities. Ecol. Let., 12, 12381249 (2009).

Fontaine, S., C. Henault, A. Aamor, N. Bdioui, J.M.G. Bloor and V. Maire: Fungi mediate longterm sequestration of carbon and nitrogen in soil through their priming effect. Soil Biol. Biochem., 43, 86-96 (2012).

Ge, T., S. Song, P. Roberts, D. L. Jones, D. Huang and K. Iwasaki: Amino acids as a nitrogen source for tomato seedlings: The use of duallabeled $(13 \mathrm{C}, 15 \mathrm{~N})$ glycine to test for direct uptake by tomato seedlings. Environ. Exp. Bot., 66, 357-361 (2009).

Gessner, M.O., C.M. Swan, C.K. Dang, B.G. McKie, R.D. Bardgett, D.H. Wall and S. Hättenschwiler: Diversity meets decomposition. Tren. Ecol. Evol., 25, 372-380 (2010).

Haynes, R.J.: Labile organic matter fractions as central components of the quality of agricultural soils: An overview. In: Advances in
Agronomy (Ed.: D.L. Sparks). Elsevier Academic Press, California, USA., p. 221-268 (2005).

Hegde, D.M.: Nutrient requirements of solanaceous vegetable crops. Asian Vegetable and Research Development Centre, Shanhua, Taiwan, 70 pages (1997).

Jayakrishna J., K.C.M. Thampatti and N. Leno: Standardisation of growth medium based on thermo chemical digest produced from degradable solid waste by rapid conversion technology. Int. J. Appl. Pure. Sci. Agric., 2, 76-80 (2016).

Jouhara, H., D. Czajczyńska, H. Ghazal, R. Krzyżyńska, L. Anguilano, A.J. Reynolds and N. Spencer: Municipal waste management systems for domestic use. Energy, 139, 485-506 (2017).

Kim, G.W., S.T. Jeong, G.Y. Kim, P.J. Kim and S.Y. Kim: Evaluation of carbon dioxide emission factor from urea during rice cropping season: A case study in Korean paddy soil. Atmos. Environ., 139,139-146 (2016).

Kochsiek, A.E. and J.M.H. Knops: Maize cellulosic biofuels: Soil carbon loss can be a hidden cost of residue removal. G.C.B. Bioenergy, 4 , 229-233 (2012).

Kukumägi, M., I. Ostonen, V. Uri, H.S. Helmisaari, A. Kanal, O. Kull and K. Lõhmus: Variation of soil respiration and its components in hemiboreal Norway spruce stands of different ages. Plant Soil, 414, 265-280 (2017).

Leno, N., C.R. Sudharmaidevi and A.V. Meera: Fertility evaluation and manurial effect of organic manure produced from degradable solid waste by rapid conversion technology. Adv. Life Sci., 5, 4433-4436 (2016).

Leno, N. and C.R. Sudharmaidevi: Biometric and yield response of banana to organic fertilizer produced by rapid decomposition of solid wastes. Trends Biosci., 10, 9284-9287 (2017).

Leno, N. and C.R. Sudharmaidevi and P.B. Mathew: Nutrient availability from an organic fertilizer produced by chemical decomposition of solid wastes in relation to dry matter production in banana. $A d v$. Res., 13, 1-9 (2017).

Leno, N. and C.R. Sudharmaidevi: Micronutrient dynamics on addition of a rapid organic fertilizer produced from degradable waste in banana. Int. J. Curr. Microbiol. App. Sci., 7, 1095-1102 (2018).

Leno, N.: Soil Carbon Sequestration: Basis and Basics. $1^{\text {st }}$ Edn., Book Publisher International, India (2020).

Leno, N., C.R. Sudharmaidevi, G. Byju, K.C.M. Thampatti, P.U. Krishnaprasad, G. Jacob and P.P. Gopinath: Thermochemical digestate fertilizer from solid waste: Characterization, labile carbon dynamics, dehydrogenase activity, water holding capacity and biomass allocation in banana. Waste Manage., 123, 1-14 (2021).

Liebig, M.A., A.J. Jones, J.W. Doran and L.N. Mielke: Potential soil respiration and relationship to soil properties in ridge tillage. Soil Sci. Soc. Am. J., 59, 430-1435 (1995).

Nair, K. M., K. S. Anil Kumar, C. Mandal, A. Chaturvedi, S. Thayalan, C. R. Kumar, V. Ramamurthy, S. Srinivas, K. Sujatha, D.H. Venkatesh, L.G.K. Naidu, D. Sarkar and P. Rajasekharan: Agroecology of Kerala. In: Soil Fertility Assessment and Information Management for Enhancing Crop Productivity in Kerala (Eds.: P. Rajasekharan, K.M. Nair, G. Rajasree, P. Sureshkumar and M. C. Narayanan Kutty). Kerala State Planning Board, pp. 54 - 71 (2013).

Ning, S., J. Song, J. Ru, Z. Zhou, J. Zhang, X. Liu, Y. Hui, Y. Ma and S. Wan: Non additive and legacy effects of spring and autumn warming on soil respiration in an old-field grassland. Ecosyst., 24, 421-433(2021)

Olaniyi, J.O. and A.T. Ajibola: Effects of inorganic and organic fertilizers application on the growth, fruit yield and quality of tomato (Lycopersicon lycopersicum). J. Appl. Biosci., 8, 236-242 (2008). 
Pan, G., P. Zhou, Z. Li, P. Smith, L. Li, D. Qiu, X. Zhang, X. Xu, S. Shen and $X$. Chen: Combined inorganic/organic fertilization enhances $N$ efficiency and increases rice productivity through organic carbon accumulation in a rice paddy from the Tai Lake region, China. Agric. Ecosys. Environ., 131, 274-280 (2009).

Prasanthi, G., N. Kumar and H. Gurumurthy: Influence of chemical parameters and microbial biomass $\mathrm{C}$ and $\mathrm{N}$ on soil mesofauna in organic farming ecosystem. J. Soil Biol. Ecol., 37, 47-54 (2017).

Ramachandra, T.V., H.A. Bharath, G. Kulkarni and S.S. Han: Municipal solid waste: Generation, composition and GHG emissions in Bangalore, India. Renew. Sustain. Energ. Rev., 82, 1122-1136 (2018).

Ramesh, T., N.S. Bolan, M.B. Kirkham, H. Wijesekara, M. Kanchikerimath, C.S. Rao, S. Sandeep, J. Rinklebe, Y.S. Ok, B.U. Choudhury and $\mathrm{H}$. Wang: Soil organic carbon dynamics: Impact of land use changes and management practices: A review. In: Advances in Agronomy (Ed.: D.L. Sparks). Vol. 156, pp. 1-107 (2019).

Ramesh, K.V., V. Paul and R. Pandey: Dynamics of mineral nutrients in tomato (Solanum lycopersicum L.) fruits during ripening: Part I- On the plant. Plant Physiol. Rep., 26, 23-37 (2021).

Rillig, M.C. and D.L. Mummey: Mycorrhizas and soil structure. New Phytol., 171, 41-53 (2006).

Samah, M.A.A., D. Victor, B. Dawda, L.A. Manaf, S.N.S. Ismail, K.B.A. Hamid, K. Yunus and M.K.A. Kamarudin: Composition and generation of municipal solid waste (MSW) in Malaysia: Balakong City Case Study. Natl. Acad. Managerial Staff Cult. Arts Herald, 3 , 1325-1331 (2018).

Sandeep, S., K.M. Manjaiah, S. Pal and A.K. Sing: Soil carbon fractions under maize-wheat system: Effect of tillage and nutrient management. Environ. Monito. Assess., 188, 1-14 (2016).

Sarauskis E., Z. Kriauciuniene, K. Romaneckas and S. Buragiene: Impact of tillage methods on environment, energy and economy. In: Sustainable Agriculture Reviews 33, Climate Impact on Agriculture (Ed.: E. Lichtfouse), pp. 53-98 (2018).

Sayer, E.J., L. Lopez-Sangil, J.A. Crawford, L.M. Bréchet, A.J. Birkett, C. Baxendale, B. Castro, C. Rodtassana, M.H. Garnett, L. Weiss and M.W. Schmidt: Tropical forest soil carbon stocks do not increase despite 15 years of doubled litter inputs. Sci. Rep., 9, 1-9 (2019).

Six, J., S.D. Frey, R.K. Thiet and K.M. Batten: Bacterial and fungal contributions to carbon sequestration in agroecosystems. Soil Sci. Soc. Am. J., 70, 555-569 (2006).

Sudharmaidevi, C.R., K.C.M. Thampatti and N. Saifudeen: Rapid production of organic fertilizer from degradable waste by thermochemical processing. Int. J. Recycl. Org. Waste Agric., 6, 111(2017).

Sun, X., Y. Ye, Q. Ma, Q. Guan and D.L. Jones: Variation in enzyme activities involved in carbon and nitrogen cycling in rhizosphere and bulk soil after organic mulching. Rhizosphere, 19, 100376 (2021).

Tun, M.M. and D. Juchelková: Assessment of solid waste generation and greenhouse gas emission potential in Yangon city, Myanmar. $J$. Mater Cycles Waste Manag., 20, 1397-1408 (2018).

Vance, E.D., P.C. Brookes and D.S. Jenkinson: Microbial biomass measurements in forest soils: Determination of $k c$ values and tests of hypotheses to explain the failure of the chloroform fumigationincubation method in acid soils. Soil Biol. Biochem., 19, 689-696 (1987).

Wang, H., J. Xu, X. Liu, D. Zhang, L. Li, W. Li and L. Sheng: Effects of long-term application of organic fertilizer on improving organic matter content and retarding acidity in red soil from China. Soil Tillage Res., 195, 104382 (2019).

Wang, X., X. Lu, F. Li and G. Yang: Effects of temperature and carbonnitrogen $(\mathrm{C} / \mathrm{N})$ ratio on the performance of anaerobic co-digestion of dairy manure, chicken manure and rice straw: focusing on ammonia inhibition. PLOS ONE, 9, 1-7 (2014).

Weil, R.R., K.R. Islam, M.A. Stine, J.B. Gruver and S.E.S. Liebig: Estimating active carbon for soil quality assessment: A simplified method for laboratory and field use. Am. J. Alterna. Agr., 18, 3-17 (2003).

Yanardağ, I.H., R. Zornoza, F. Bastida, A. Büyükkiliç-Yanardağ, C. García, A. Faz and A.R. Mermut: Native soil organic matter conditions the response of microbial communities to organic inputs with different stability. Geoderma, 295,1-9 (2017). 